\title{
ESTIMATION OF BLOOD VOLUME FROM CHANGE IN BLOOD SPECIFIC GRAVITY FOLLOWING A PLASMA INFUSION ${ }^{1,2}$
}

\author{
By R. A. PHILLIPS, ${ }^{3}$ A. YEOMANS, ${ }^{3}$ V. P. DOLE, ${ }^{3}$ L. E. FARR, ${ }^{3}$ aND D. D. VAN SLYKE \\ WITH THE TECHNICAL ASSISTANCE OF DAVID HOGAN 4 \\ (From the Laboratory of the Hospital of The Rockefeller Institute for Medical Research and the \\ United States of America Typhus Commission Unit at the Cairo Fever Hospital)
}

(Received for publication December 15, 1945)

In the treatment of wounded men in shock, the rapid intravenous infusion of plasma is almost a routine preliminary to prevent further deterioration of the clinical condition of the patient, while the extent of injuries and the clinical condition are evaluated. If one can add to this evaluation a quick approximation of the blood volume obtained by estimating the dilution caused by the infused plasma, one will have information of value in deciding further therapy.

This paper presents data which indicate that the blood volume can be estimated, within \pm 15 per cent, from the decrease in blood specific gravity caused by infusion of a known volume of isosmotic plasma or albumin solution. The specific gravity determinations on the 3 samples, blood drawn before the infusion, blood drawn 5 to 10 minutes after the infusion, and infused plasma or albumin, can be quickly and accurately determined by the copper sulfate method (1). About 2 minutes suffice for the specific gravity determinations and the calculation of blood volume from the appended line chart. This method of estimating blood volume will be called Procedure A.

An alternative procedure, $B$, is to estimate blood volume from the decrease in hemoglobin concentration caused by infusion of a known volume of isosmotic plasma or albumin solution.

\footnotetext{
1 These studies were supported in part by a contract, recommended by the Committee on Medical Research, between the Office of Scientific Research and Development and The Rockefeller Institute for Medical Research.

2 This article has been released for publication by the Division of Publications of the Bureau of Medicine and Surgery of the U. S. Navy. The opinions and views set forth in this article are those of the writers and are not to be considered as reflecting the policies of the Navy Department.

${ }^{3}$ Lieutenant Commander, Medical Corps, United States Naval Reserve.

T/5, A.U.S.
}

When the hemoglobin is determined by the copper sulfate method, the procedure requires, in addition to measurement of the specific gravities of the 2 blood samples, measurement of the specific gravities of their plasmas also. Hence, Procedure B is less desirable than A for rapid work. Results by the two procedures check closely, however.

In the present paper, blood volumes measured by the above procedures are compared with blood volumes simultaneously determined by the usual dye method.

\section{ESTIMATION OF WHOLE BLOOD VOLUME FROM CHANGE IN BLOOD SPECIFIC GRAVITY (PROCEDURE A)}

Technique of Procedure A. A sample of blood $\left(B_{1}\right)$ is drawn. From 500 to $1500 \mathrm{ml}$. of normal plasma, or of lyophilized plasma made up to contain about 8 per cent of solids, or of approximately 5 per cent human albumin solution, are rapidly infused (50 to $100 \mathrm{ml}$. per minute).5 Five to 10 minutes after completion of the infusion a second sample of blood $\left(B_{2}\right)$ is drawn.

Whole blood specific gravities, $G_{B_{1}}$ and $G_{B_{2}}$, of blood samples $B_{1}$ and $B_{2}$ are then determined (1), also the

- The larger the volume of plasma or albumin solution infused the more accurate will be the blood volume estimation: Five hundred $\mathrm{ml}$. is the smallest volume that will yield a usefully accurate blood volume figure. (See discussion of "Relative effects of different sources of error.") If the subject's plasma is grossly below normal in protein concentration, blood volume somewhat too low may be estimated by injection of plasma of normal concentration. Theoretically, such plasma, injected into a subject with hypoproteinemia, should draw extravascular water into the circulation, and thereby decrease $G_{B_{2}}$. As seen by inspection of Equation, 2 decrease in $G_{B_{2}}$ affects both numerator and denominator of the right hand member of the equation in a way to decrease the calculated $V_{B_{1}}$. The results at the top and bottom of Table II, exemplify the errors that can be caused in estimated blood volume when the infusions are grossly hyperosmotic or hypoosmotic. However, when the second blood sample is drawn within a few minutes after normal plasma infusion, the error caused by osmotic effects appears not to be great. 

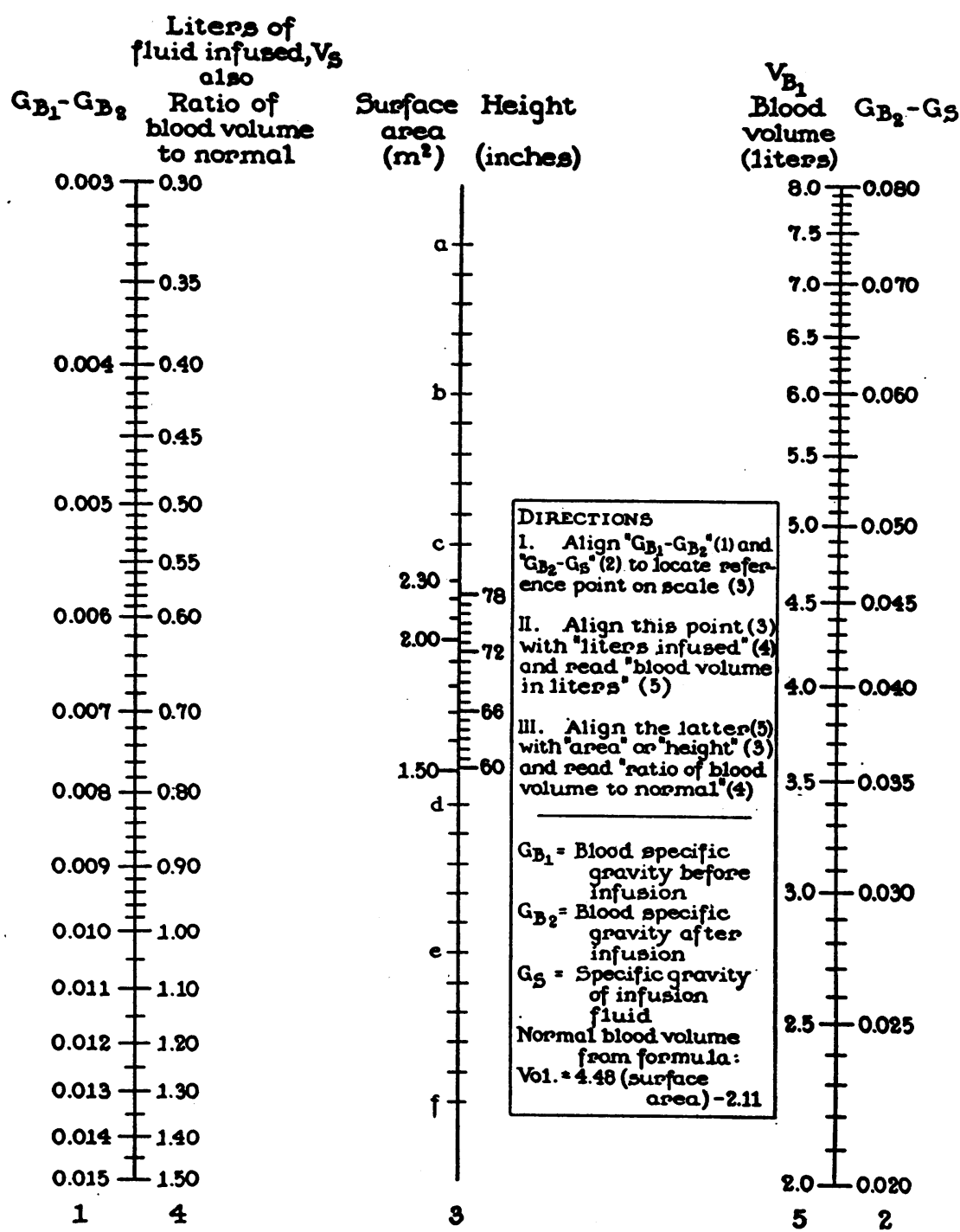

Fig. 1. Calculation of Blood Volume from the Change In Blood Gravity Due to Infusion of Plasma or Similar Fluid

specific gravity, $G_{\boldsymbol{\theta}}$, of the infused protein solution. These values, together with the volume $V$. of the infused solution, are used to calculate the whole blood volume by Equation 2 or the line chart of Fig. 1.

The blood samples should be drawn into dry syringes. One ml. samples of blood are adequate, unless other analyses are desired. An anticoagulant is usually unnecessary as the specific gravities can be determined at once by dropping blood from the syringe into the copper sulfate solutions. However, if it is desirable to use anticoagulant and determine the specific gravities later, heparin, $0.2 \mathrm{mgm}$. per ml. of blood, is the ideal anticoagulant while the oxalate mixture of Heller and Paul (2) is almost as satisfactory. (For precautions in technique when an anticoagulant is not used see Reference 1.)
Calculation of blood volume. The principle of estimating blood volume from blood specific gravity change caused by infusion of a fluid lighter than blood was introduced in 1893 by Sherrington and Copeman (3). Sherrington and Copeman infused $\mathrm{NaCl}$ solutions. These solutions, since they contained no protein, diffused out of the circulation so rapidly that, to obtain consistent results, it was necessary to make the infusions in a few seconds and draw the second blood sample 30 seconds later. The use of plasma should decrease this diffusion and thus render their procedure more accurate. That 
TABLE I*

Comparison of blood volumes estimated by Procedure A (Blood Specific Gravity Change), Procedure $B$ (Hemoglobin Change) and by the dye method

\begin{tabular}{|c|c|c|c|c|c|c|c|c|c|c|c|c|c|c|c|}
\hline \multirow{3}{*}{$\begin{array}{l}\text { Pt. } \\
\text { no. }\end{array}$} & \multirow{3}{*}{ Age } & \multirow{3}{*}{$\begin{array}{l}\text { Sur- } \\
\text { face } \\
\text { area }\end{array}$} & \multirow{3}{*}{$\begin{array}{c}\begin{array}{c}\text { Volume } \\
\text { of } \\
\text { infused } \\
\text { solution } \\
\mathrm{A}=\text { albu- } \\
\text { min } \\
\mathrm{P}=\text { plas- } \\
\text { ma }\end{array} \\
\mathrm{V}\end{array}$} & \multicolumn{7}{|c|}{ Determined by CuSO4 method } & \multicolumn{5}{|c|}{ Whole blood volume before infusion $\dagger$} \\
\hline & & & & \multicolumn{2}{|c|}{$\begin{array}{l}\text { Whole blood } \\
\text { specific gravity }\end{array}$} & \multicolumn{2}{|c|}{$\begin{array}{c}\text { Plasma specific } \\
\text { gravity }\end{array}$} & \multirow{2}{*}{$\begin{array}{c}\text { Specific } \\
\text { gravity } \\
\text { of } \\
\text { infused } \\
\text { solution }\end{array}$} & \multicolumn{2}{|c|}{$\begin{array}{c}\text { Hemoglobin } \\
\text { concentration }\end{array}$} & \multirow{2}{*}{$\begin{array}{c}\text { Dye } \\
\text { meth- } \\
\text { od }\end{array}$} & \multirow{2}{*}{$\begin{array}{l}\text { Proce- } \\
\text { dure A. } \\
\text { Equa- } \\
\text { tion 2 }\end{array}$} & \multirow{2}{*}{$\begin{array}{l}\text { Proce- } \\
\text { dure B. } \\
\text { Equa- } \\
\text { tion } 3\end{array}$} & \multicolumn{2}{|c|}{$\begin{array}{l}\text { As percentage of } \\
\text { volume by dye } \\
\text { method }\end{array}$} \\
\hline & & & & $\begin{array}{c}\text { Before } \\
\text { infusion } \\
G_{B_{1}}\end{array}$ & $\begin{array}{c}\begin{array}{c}\text { After } \\
\text { infusion }\end{array} \\
G_{B_{2}}\end{array}$ & $\begin{array}{c}\text { Before } \\
\text { infusion }\end{array}$ & $\begin{array}{c}\text { After } \\
\text { infusion }\end{array}$ & & $\begin{array}{c}\text { Before } \\
\text { infu- } \\
\text { sion }\end{array}$ & $\begin{array}{c}\text { After } \\
\text { infu- } \\
\text { sion }\end{array}$ & & & & $\begin{array}{l}\text { Proce- } \\
\text { dure A }\end{array}$ & $\begin{array}{l}\text { Proce- } \\
\text { dure B }\end{array}$ \\
\hline $\mathbf{a}$ & b & c & d & e & f & $\mathbf{g}$ & $\mathbf{h}$ & $\mathbf{i}$ & $\mathbf{j}$ & $\mathbf{k}$ & $\mathbf{m}$ & $\mathbf{n}$ & o & p & $\mathbf{q}$ \\
\hline $\begin{array}{l}1 \\
2 \\
3 \\
4 \\
5 \\
6 \\
7 \\
8\end{array}$ & $\begin{array}{l}y r s . \\
45 \\
36 \\
35 \\
40 \\
48 \\
36 \\
25 \\
23\end{array}$ & $\begin{array}{l}M^{2} \\
1.67 \\
1.66 \\
1.58 \\
1.60 \\
1.64 \\
1.66 \\
1.47 \\
1.72\end{array}$ & $\begin{array}{l}\text { liters } \\
1.40 \mathrm{~A} \\
1.50 \mathrm{~A} \\
1.50 \mathrm{~A} \\
1.50 \mathrm{~A} \\
1.20 \mathrm{P} \\
1.50 \mathrm{~A} \\
1.55 \mathrm{P} \\
1.50 \mathrm{~A}\end{array}$ & $\begin{array}{l}1.0528 \\
1.0540 \\
1.0535 \\
1.0530 \\
1.0510 \\
1.0520 \\
1.0498 \\
1.0552\end{array}$ & $\begin{array}{l}1.0470 \\
1.0475 \\
1.0458 \\
1.0470 \\
1.0462 \\
1.0472 \\
1.0435 \\
1.0500\end{array}$ & $\begin{array}{l}1.0265 \\
1.0272 \\
1.0265 \\
1.0250 \\
1.0222 \\
1.0280 \\
1.0222 \\
1.0268\end{array}$ & $\begin{array}{l}1.0262 \\
1.0270 \\
1.0250 \\
1.0248 \\
1.0230 \\
1.0274 \\
1.0230 \\
1.0270\end{array}$ & $\begin{array}{l}1.0260 \\
1.0265 \\
1.0215 \\
1.0245 \\
1.0238 \\
1.0272 \\
1.0235 \\
1.0275 \\
\text { Avera }\end{array}$ & \begin{tabular}{|c} 
grams \\
per \\
$100 \mathrm{ml}$. \\
12.65 \\
13.02 \\
12.98 \\
13.18 \\
13.05 \\
11.79 \\
12.50 \\
13.71 \\
\\
ee of 8
\end{tabular} & $\begin{array}{c}\text { grams } \\
\text { per } \\
100 \mathrm{ml} . \\
9.96 \\
9.93 \\
9.80 \\
10.43 \\
10.63 \\
9.64 \\
9.38 \\
11.14\end{array}$ & $\begin{array}{l}\text { liters } \\
5.84 \\
5.33 \\
5.01 \\
5.57 \\
5.45 \\
6.04 \\
4.63 \\
5.73 \\
5.45\end{array}$ & $\begin{array}{l}\text { liters } \\
\\
5.08 \\
4.85 \\
4.74 \\
5.63 \\
5.61 \\
6.26 \\
4.93 \\
6.48 \\
\\
5.45\end{array}$ & $\begin{array}{l}\text { liters } \\
5.23 \\
4.90 \\
4.63 \\
5.70 \\
5.28 \\
6.72 \\
4.66 \\
6.66 \\
\\
5.47\end{array}$ & $\begin{array}{r}\text { per } \\
\text { cent } \\
87 \\
91 \\
95 \\
101 \\
103 \\
104 \\
106 \\
113 \\
\\
100\end{array}$ & $\begin{array}{r}\text { per } \\
\text { cent } \\
90 \\
90 \\
92 \\
92 \\
102 \\
97 \\
111 \\
101 \\
116 \\
\\
100\end{array}$ \\
\hline
\end{tabular}

* These determinations were made in the United States of America Typhus Commission Unit at the Cairo Fever Hospital, Cairo, Egypt.

$\dagger$ The average blood volume of the 8 subjects per square meter surface area found by the dye method was 3.35 liters, by Procedure A 3.35, by Procedure B 3.36. Rowntree and Brown (4) found 3.37 as the average of 49 normal men. It is evident that the patients here reported had normal blood volumes.

TABLE II

Effects of variation in colloidal osmotic pressure of infused solution on blood volumes estimated from hematocrit change (Procedure B), calculated from data of Lowell, Cournand and Richards (16)

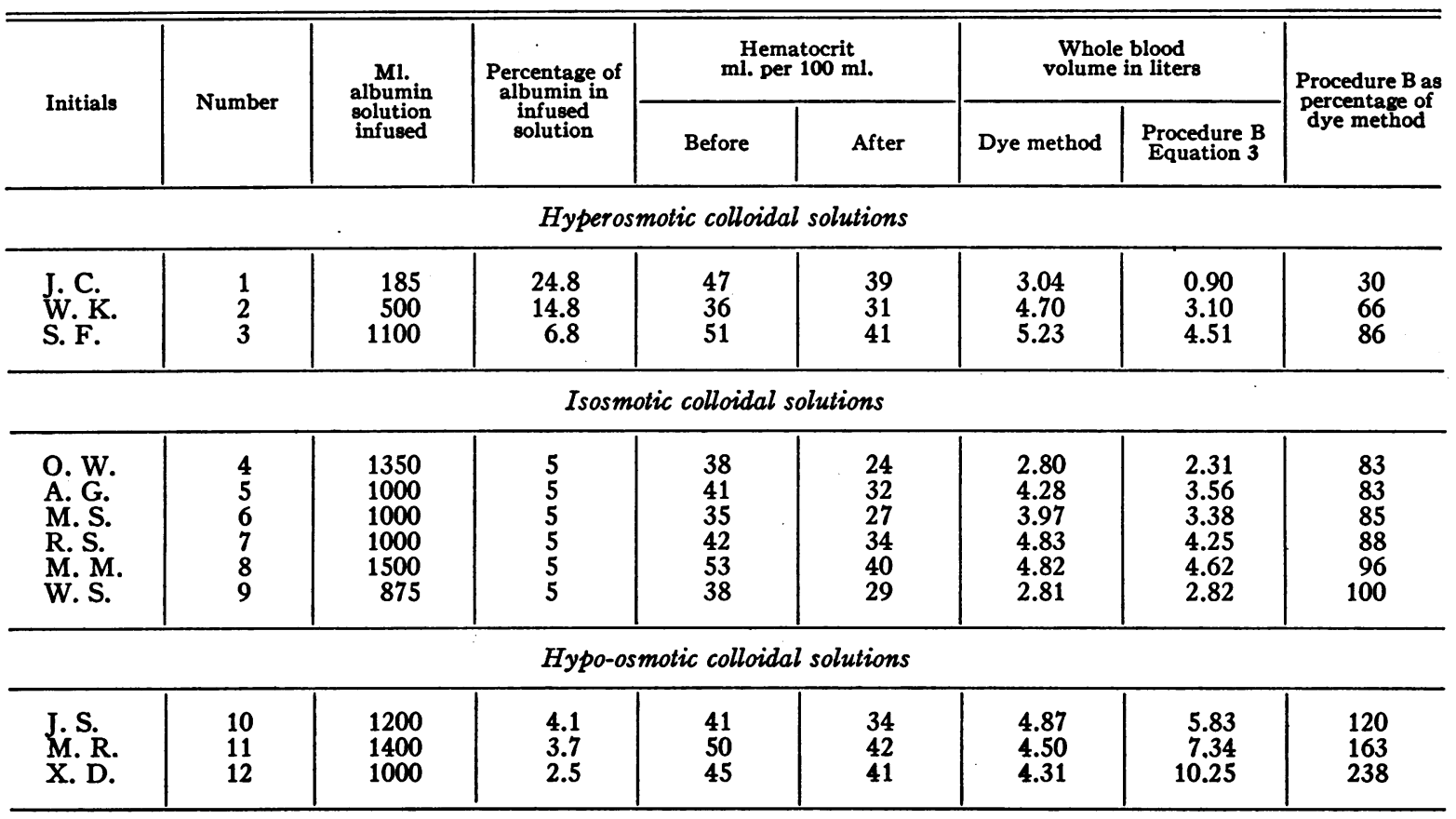


this is the case is shown in the results in Tables I and II.

Let $V_{B_{1}}=$ blood volume before plasma infusion.

$G_{B_{1}}=$ blood specific gravity before plasma infusion.

$G_{B_{2}}=$ blood specific gravity after plasma infusion.

- $\quad V_{\mathrm{s}}=$ volume of plasma infused.

$G_{s}=$ specific gravity of plasma infused.

Equating two values for weight of whole circulating blood plus infused albumin solution or plasma (weight $=$ volume $\times$ specific gravity) we have

$$
\underbrace{V_{B_{1}} G_{B_{1}}+V_{s} G_{8}}_{\begin{array}{c}
\text { Sum of weights } \\
\text { before infusion }
\end{array}}=\underbrace{\left(V_{B_{1}}+V_{8}\right) G_{B_{2}}}_{\begin{array}{c}
\text { Weight in circulation } \\
\text { after infusion }
\end{array}}
$$

whence:

$$
V_{B_{1}}=V_{3}\left(\frac{G_{B_{2}}-G_{8}}{G_{B_{1}}-G_{B_{2}}}\right)
$$

Calculation of ratio of observed blood volume to normal blood volume. When the subject is an adult man one may further use the chart to estimate the ratio of observed blood volume to the volume that is normal for the subject's size. As shown in Table I, the specific gravity method for blood volume gives the same values as the dye method. Blood volumes determined in normal adult men by the dye method have been found by Rowntree, Brown and Roth (4, p. 64) to be related to surface area according to the formula, Blood volume (liters) $=4.48 \mathrm{~A}-2.11$, where $A$ is surface area in square meters. (In women it is 7 per cent less per $\mathrm{M}^{2}$, and in children it is much less.) Hence for men, the ratio of observed blood volume to normal blood volume is calculated by Equation 3.

(3) $\frac{\text { Observed blood volume }}{\text { Mean normal blood volume }}=\frac{V_{B_{1}}}{4.48 A-2.11}$

The surface area can be calculated by $\mathrm{Du}$ Bois' formula:

$$
\text { Area in } \mathrm{M}^{2}=\left(H^{0.725} \times W^{0.425}\right) 0.007184
$$

where $H$ is height in $\mathrm{cm}$., and $W$ is weight in kgm. Various manuals contain line charts for graphic estimation of surface area by the above formula.
McIntosh, M $\varnothing$ ller, and Van Slyke (5) have computed a curve relating height to surface area; these two values closely correlate except in adult subjects of very abnormal build. Hence when surface area cannot be computed, height values may be substituted in estimating the blood volume that would be normal for the subject. The line chart in Figure 1 enables one to use either surface area or the equivalent height.

\section{USE OF NOMOGRAM TO CALCULATE BLOOD VOLUME MEASURED BY PROCEDURE A}

To calculate the blood volume, $V_{B_{1}}$ (Equation 2 ), first make the subtraction, $G_{B_{1}}-G_{B_{2}}$, to find the decrease in blood specific gravity caused by the infusion, and the subtraction, $G_{B_{2}}-G_{8}$, to find the specific gravity difference between the infused fluid and the subject's blood drawn after the infusion. $V_{B_{1}}$ is then estimated by aligning a straight-edge (a transparent ruler or, preferably, a silk thread) twice across the line chart (Figure 1). The first alignment gives the quotient $\left(G_{B_{2}}-G_{8}\right) /\left(G_{B_{1}}-G_{B_{2}}\right)$ (see Equation 2); the second alignment multiplies the quotient by $V_{8}$ to give the desired $V_{B_{1}}$.

For the first alignment, locate the point for $G_{B_{1}}-G_{B_{2}}$ on Scale 1 at the left side of the chart and the point for $G_{B_{2}}-G_{s}$ on Scale 2 at the right side. Lay the straight edge through these two points and note the point where it intersects Scale 3 in the middle of the chart. (The numbers on Scale 3 do not indicate the numerical value of the quotient, which is unnecessary to know, but aid in locating the intersection point for use in the second alignment.) The second alignment is now made by laying the straight-edge through the previously located intersection point on Scale 3 and through the point on Scale 4 that indicates $V_{s}$, the liters of solution infused. The intersection of the straight-edge with Scale 5 indicates the blood volume sought.

To determine the ratio of the observed blood volume to the average blood volume normal for an adult male of the size of the subject, a third alignment may be made. The straight-edge is laid across the point found on Scale 5 for $V_{B_{1}}$ and the point on Scale 3 that indicates either the surface area or the height of the subject. The point where the straight-edge cuts Scale 4 indicates the ratio. 
Example. The data on Patient 1 of Table I serve for an example. $G_{B_{1}}-G_{B_{2}}=1.0528$ $-1.0470=0.0058$. $G_{B_{2}}-G_{s}=1.0470$ $-1.0260=0.0210$. The first alignment across the point 0.0058 on Scale 1 and point 0.0210 on Scale 2, intersects Scale 3 at a point 3.3 divisions above the mark $e$. The second alignment is made across this intersection point on Scale 3 and the point on Scale 4 that indicates 1.40 , the liters of albumin solution infused into $\mathrm{Pa}$ tient 1. The straight-edge then cuts Scale 5 to indicate a blood volume of 5.07 liters.

To find the ratio of this blood volume to that normal for the subject's size, the straight-edge is laid across the point on Scale $\mathbf{5}$ for $\mathbf{5 . 0 7}$ liters and the point on Scale 3 for 1.67 square meters of surface area (Table I). The value 0.95 is read where the straight-edge cuts Scale 4, indicating that the blood volume of the patient was 95 per cent of the mean normal for a man of his size.

\section{ESTIMATION OF WHOLE BLOOD VOLUME FROM CHANGE IN HEMOGLOBIN CONCENTRATION OR HEMATOCRIT (PROCEDURE B)}

Valentin in 1838 (6) is given credit by Erlanger (7) for first pointing out that one can estimate the blood volume by the following formula:

$$
V_{B_{1}}=V_{\cdot}\left(\frac{H b_{2}}{H b_{1}-H b_{2}}\right)
$$

$V_{B_{1}}$ and $V_{2}$ have the same significance as in Equations 1 and 2.

$H b_{1}=$ hemoglobin concentration before infusion.

$H b_{2}=$ hemoglobin concentration after infusion.

For $H b_{1}$ and $H b_{2}$ in Equation 3, one can substitute hematocrit values, provided the cells do not swell or shrink during the infusion.

\section{EXPERIMENTAL}

\section{GENERAL PROCEDURE OF EXPERIMENTS}

First, a preliminary sample of blood was drawn from the right arm. This sample served two purposes: (1) Determination of the hematocrit value, used to calculate whole blood volume from the dye-estimated plasma volume. This hematocrit value was estimated from the specific gravities of the whole blood and plasma determined by the copper sulfate method. (2) Preparation of a reference solution of dye in plasma for photometric comparison with the plasma drawn after dye injection.

After drawing the preliminary blood sample, a measured volume of dye solution was injected into a left arm vein, and after 5 minutes ${ }^{6}$ either one or two samples of blood were drawn from the right arm for estimation of dye concentration in the plasma.

The last sample drawn for dye determination served to determine also the pre-infusion specific gravity, $G_{B_{1}}$, of the blood before infusion of plasma or albumin solution.

Within 15 minutes after the blood sample for $G_{B_{1}}$ was drawn, infusion of plasma or albumin solution was begun. The infusion rate varied from 30 to $90 \mathrm{ml}$. per minute, and the volume infused varied from 1200 to $1500 \mathrm{ml}$. Within 5 to 15 minutes after the infusion was completed a sample of blood was drawn to determine the post-infusion specific gravity, $G_{B_{2}} . G_{B_{1}}, G_{B_{2}}$, and $G_{8}$ provided the specific gravity data for estimation of blood volume by Procedure A.

In order to obtain check determinations of blood volume by Procedure $\mathrm{B}$, samples of bloods $B_{1}$ and $B_{2}$ were centrifuged and plasma specific gravities, in addition to whole blood specific gravities, were determined. From the specific gravities of whole blood and plasma of each sample the hemoglobin concentration was calculated, as previously described (1).

\section{ESTIMATION OF PLASMA VOLUME AND WHOLE BLOOD VOLUME BY THE DYE METHOD}

Estimation of the blood volume from the dilution in the plasma or a known amount of injected dye, $\mathrm{T}-1824$, and from the true cell volume (hematocrit corrected for the "trapped plasma") gives reproducible values for blood volume, which from comparison with blood volumes determined by the carbon monoxide method and other procedures, appear to be within \pm 5 per cent of the true volume of circulating blood $(5,6)$. Because of ease of procedure, the dye method was selected for comparison of the results obtained by the copper sulfate method in Procedures A and B.

Reference solution. To serve as standard for photometric dye measurement, a reference solution of dye in the patient's plasma was prepared in such a manner that the dilution of the dye was equal to the dilution that would be obtained if the same amount of dye were injected into a subject with a plasma volume of 5 liters. Thus, of the identical approximately 0.4 per cent dye solution to be injected, a volume equal to that injected (ca. $5 \mathrm{ml}$.) was diluted to $1000 \mathrm{ml}$. with 0.9 per cent $\mathrm{NaCl}$ solution, and one ml. of this dilute solution was mixed with $5 \mathrm{ml}$. of undyed plasma from the preliminary blood sample. The use of this reference solution to determine $D_{R}$ (see Equation 5) automatically corrected for the change in extinction coefficient which T-1824 undergoes when dissolved in

- The assumption that mixing is complete in $\mathbf{5}$ minutes is validated in the following references ( 7 to 11 ). 
plasma (14). Also, preparation of the reference solution from the identical dye solution used for injection eliminated error from concentration differences of dye in different ampoules, and eliminated the necessity of determining the extinction coefficient.

Measurement of equal portions of dye solution for reference solution and for injection. The technique used required the use of two exactly equal portions of approximately $5 \mathrm{ml}$. of 0.4 per cent aqueous dye solution from the same ampoule of dye which had been sterilized by autoclaving. One portion was for intravenous injection into the patient, and the other for preparation of the reference solution. For measuring the two portions, a $10 \mathrm{ml}$. graduated syringe was used. This was calibrated as suggested by Gregersen (15) by marking the plunger with a line that permitted deliveries of identical volumes of approximately $5 \mathrm{ml}$. of solution. Exact duplication of the same volume rather than exact measurement of $5 \mathrm{ml}$. was required.

Injection of dye. The same volume of 0.4 per cent dye solution ( $c a .5 \mathrm{ml}$.) used in preparing the reference solution, was injected into the left antecubital vein. Five minutes after the dye injection was finished a second sample of blood was drawn, from the right arm. Usually a third blood sample was drawn 10 minutes after the dye injection, for a check determination of the dye concentration.

Comparison of optical density of dye in post-injection plasma with density in reference solutions. Both optical densities were measured with a Coleman Junior spectrophotometer, using light of $620 \mathrm{~m} \mu$ wave length, matched cuvettes of approximately $19 \mathrm{~mm}$. diameter, and a water blank.

Calculations. Plasma volume was calculated by Equation (5).

$$
\text { Plasma volume (liters) }=5\left(\frac{D_{R}-a}{D_{V}-a}\right)
$$

$D_{R}$ indicates the optical density of the reference solution.

$D_{V}$ indicates the optical density of the subjects' plasma (plus 0.2 volume of saline) after the dye injection.

$a$ indicates the optical density of plasma constituents other than the dye.

The value of $a$ (Equation 5) was usually determined in a preliminary analysis as the optical density of a mixture of $5 \mathrm{ml}$. of undyed plasma (from the subject's preliminary blood sample), and $1 \mathrm{ml}$. of 0.9 per cent $\mathrm{NaCl}$ solution, water being used as the blank.

In some cases the preliminary blood sample did not yield enough plasma for the two $5 \mathrm{ml}$. samples required to prepare the reference solution and to determine the $a$ as above described by comparison with water. In such cases $a$ was determined by a procedure based on the assumption that the extinction coefficient of the dye was the same in the plasmas of all the patients. (This assumption was confirmed by repeated tests.) Undyed plasma from all patients which was left over after other plasma analyses, was pooled. Optical densities were determined on the following: (I) Five ml. of pooled plasma mixed with $1 \mathrm{ml}$. of the diluted dye (ca. $5 \mathrm{ml} .0 .4$ per cent to $1000 \mathrm{ml}$.). (II) Another $5 \mathrm{ml}$. portion of the pooled plasma mixed with $1 \mathrm{ml}$. of 0.9 per cent $\mathrm{NaCl}$ solution. (III) The reference solution prepared with the patient's plasma. The difference (IV) in optical density between (I) and (II) thus represented the optical density due to the dye when the measured amount was dissolved in a mixture of $1 \mathrm{ml}$. of salt solution and $5 \mathrm{ml}$. of plasma. (V) This difference was subtracted from the optical density of the patient's reference solution to obtain $a$, the density due to plasma constituents. This procedure was found to give the same $a$ values as did the direct measurement of $a$.

The measurements and subtractions involved in the above steps may be indicated as follows:

$$
\begin{aligned}
\text { (I) } & =D_{\text {dye in any plasma }}+a_{\text {pooled plasma }} \\
\text { (II) } & =a_{\text {pooled plasma }} \\
\text { (III) } & =D_{\text {dye in any plasma }}+a_{\text {patient's plasma }} \\
\text { (IV) } & =(\mathrm{I})-(\text { II })=D_{\text {dye in any plasma }} \\
\text { (V) } & =\text { (III) }- \text { (IV) }=a_{\text {patient's plasma }}
\end{aligned}
$$

The whole blood volume was calculated as

(6) Whole blood volume $=100\left[\frac{\text { Plasma volume }}{(100-\text { true cell volume })}\right]$

The "true cell volume" (ml. of cells per $100 \mathrm{ml}$. of whole blood) used in Equation 6 was estimated from the hematocrit number. The hematocrit number calculated from blood and plasma specific gravities (1) has been found to include with the cells some 4.5 per cent of "trapped plasma." True cell volume was therefore calculated by multiplying the copper sulfate hematocrit value by the factor $\mathbf{0 . 9 5 5}$.

\section{ESTIMATIONS OF WHOLE BLOOD VOLUME BY SPECIFIC GRAVITY PROCEDURES A AND B}

Procedure $\mathrm{A}$ was carried out as described in the first part of this paper. For Procedure B, portions of the heparinized blood samples drawn before and after infusion of plasma or albumin solution, were centrifuged, and plasma specific gravities were determined. The hemoglobin concentrations were estimated, from whole blood and plasma specific gravities, by the nomogram of Phillips, et al. (1), and used for calculation of blood volume by Equation 4.

The plasma and albumin solutions for infusion were made up to have specific gravities approximately equal to that of the patient's plasma. The specific gravities were thus adjusted, because in some instances the patients were dehydrated while others had depleted plasma proteins and it was desired to minimize the error from such abnormalities (footnote to page 2). The solutions were prepared by so diluting either lyophilized solid plasma with water, or 25 per cent human albumin solution with 0.9 per cent sterile $\mathrm{NaCl}$ solution, that the specific gravity of the 
solution to be infused, determined by the copper sulfate method, approximated the specific gravity of the plasma of blood drawn from the patient on the preceding day. Because albumin has greater osmotic activity per gram than the plasma globulins, the albumin solutions injected were presumably of somewhat greater colloidal osmotic activity than the patient's plasma, but the results indicated that the difference was not enough to cause significant hemodilution by drawing in extravascular water before the post-injection sample of blood was taken.

Example of experiment and calculations: (Patient 101427 February 1945. Weight, $123 \frac{1}{2}$ lbs., Height, $66 \frac{1}{2}$ inches, Surface Area, 1.64 $\mathrm{M}^{2}$.)

(1) $5.4 \mathrm{ml}$. T-1824 injected into $100 \mathrm{ml}$. volumetric flask and made up to $100 \mathrm{ml}$. with 0.9 per cent solution of $\mathrm{NaCl}$.

(2) Ten ml. of (1) diluted to $100 \mathrm{ml}$. with 0.9 per cent solution of $\mathrm{NaCl}$, forming a 1:1000 dilution of dye.

(3) 11:04 a.m.-Twenty ml. of blood withdrawn from patient and transferred to a $20 \mathrm{ml}$. lusteroid tube containing $1 \mathrm{mgm}$. heparin $\left(B_{a}\right)$.

(4) 11:05:30 a.m.-Identical volume of dye used in (1) injected intravenously into patient's left arm.

(5) $11: 11$ a.m.-Fifteen ml. of blood for sample $B_{1}$ drawn.

(6) 11:13 a.m.- Infusion of human plasma started.

(7) 11:56 a.m.-Infusion of $1200 \mathrm{ml}$. of plasma completed.

(8) $12: 10$ p.m.-Blood sample $B_{2}$ drawn.

(9) Analyses.

Optical densities.

a. $5 \mathrm{ml}$. Plasma from $B_{a}$ $+1 \mathrm{ml} .0 .9$ per cent $\mathrm{NaCl}$

$D_{R} .5 \mathrm{ml}$. Plasma from $B_{a}$ . $1 \mathrm{ml}$. of 1:000 dye (2)

$D_{V} .5 \mathrm{ml}$. Plasma from $B_{1}$ $+1 \mathrm{ml} .0 .9$ per cent $\mathrm{NaCl}$

Specific gravities.

\begin{tabular}{l|c|c|c|c}
\hline Sample & $\begin{array}{c}\text { Whole } \\
\text { blood } \\
\text { specific } \\
\text { gravity }\end{array}$ & $\begin{array}{c}\text { Plasma } \\
\text { specific } \\
\text { gravity }\end{array}$ & $\begin{array}{c}\text { True cell } \\
\text { volume }\end{array}$ & $\begin{array}{c}\text { Grams } \\
\text { Hb per } \\
100 \mathrm{ml} \\
\text { blood }\end{array}$ \\
\hline $1200 \mathrm{ml}$. of in- \\
fused plasma & & 1.0238 & & \\
$B_{1} B_{3}$ & 1.0510 & 1.0222 & 36.8 & 13.05 \\
\hline
\end{tabular}

(10) Calculations of results by dye method.

Plasma volume (Equation 5) $=5000\left(\frac{D_{R}-a}{D_{V}-a}\right)$
$\quad=5000\left(\frac{0.678-0.328}{0.837-0.328}\right)=3440 \mathrm{ml}$.

Whole blood volume (Equation 6)

$$
=100\left(\frac{3440}{100-36.8}\right)=5450 \mathrm{ml} .
$$

Plasma volume per square meter surface area

$$
=\frac{3440}{1.64}=2100 \mathrm{ml} \text {. per } \mathrm{M}^{2} \text {. }
$$

Whole blood volume per square meter surface area

$$
=\frac{5450}{1.64}=3320 \mathrm{ml} \text {. per } \mathrm{M}^{2} \text {. }
$$

(11) Comparison of results by three methods.

$\begin{array}{ccc}\begin{array}{c}\text { Method of } \\ \text { measurement }\end{array} & \begin{array}{c}\text { Whole blood } \\ \text { volume in } \\ \text { ml. per M2. }\end{array} & \begin{array}{c}\text { Whole blood } \\ \text { volume as } \\ \text { percentage of } \\ \text { value by dye } \\ \text { method }\end{array} \\ \begin{array}{c}\text { Dye method } \\ \text { Procedure A }\end{array} & 3320 & \\ \text { Procedure B } & 3420 & 103 \\ \text { Prot } & 3220 & 97\end{array}$

\section{RESULTS OF PRESENT BLOOD VOLUME ESTIMATIONS}

Table I compares the whole blood volume as estimated by the dye method (column $\mathrm{m}$ ) with the estimations made by Procedure A (column n) and Procedure B (column o) in 8 patients with typhus fever. The values obtained by Procedure $A$ are expressed as percentages of the values obtained by the dye method in column $\mathrm{p}$; the agreement with results by the dye method is within \pm 13 per cent. Comparable agreement with the dye method (column q) was obtained by Procedure $B$. The average of blood volumes found in the 8 subjects was almost the same by each method (columns $\mathrm{m}, \mathrm{n}$ and $\mathrm{o}$ ), showing that plus and minus deviations of Procedures $\mathrm{A}$ and $B$ from the results of the dye method were about equal.

\section{BLOOD VOLUMES CALCULATED FROM DATA OF} LOWELL, COURNAND, AND RICHARDS (16)

Through the courtesy of Drs. Alice Lowell, Andre Cournand and Dickinson W. Richards, we are able to include the data in Table II. In this table the blood volume estimated by the dye method is compared with the blood volume estimated from the change in hematocrit (Pro- 
cedure B). The hematocrits were obtained by centrifugation and no correction for trapped plasma was made. These patients were all in shock at the time the albumin was injected.

The data serve to show the nature of the error in calculated blood volumes that can be caused when the infused plasma or albumin solution differs greatly from the patient's plasma in colloidal osmotic pressure. The first 3 patients received albumin solutions with colloidal osmotic pressures markedly above that of normal plasma, while patients 4 to 9 received 5 per cent albumin, of approximately the pressure of normal plasma, and patients 10 to 12 received hypo-osmotic solutions.

The time relations concerning the injection of infusions and the drawing of the blood samples were such as to give osmotic abnormalities in the infused solutions opportunity to cause greater error in the calculated blood volumes than would be permitted by the timing prescribed in this paper. The duration of the infusions varied from 30 to 60 minutes, which was longer than in the patients of Table I; and the time elapsing between completion of the infusion and the subsequent drawing of blood for the post-infusion hematocrit averaged over 30 minutes, instead of the 5 to 15 minutes prescribed in this paper.

From the results with isosmotic colloidal solutions in Table II (patients 4 to 9), it appears that Procedure B, and by analogy Procedure A, can be used to estimate the blood volume of man in shock if a solution of approximately isosmotic colloidal pressure is infused. Presumably if the post-infusion blood samples had been drawn 5 to 15 minutes after the infusions were completed, instead of 30 or more minutes afterwards and exact hemoglobin concentrations had been measured instead of hematocrits, the blood volumes estimated by concentration changes would have been still closer to the volumes estimated by the dye method.

\section{RELATIVE EFFECTS OF DIFFERENT SOURCES OF ERROR IN BLOOD VOLUME MEASUREMENTS BY THE SPECIFIC GRAVITY METHOD}

Volume of injected solution. As seen from Equation 1, the error in estimated blood volume $V_{B_{1}}$ is directly proportional to the error in measuring the volume, $V_{s}$, of injected plasma. Under ideal conditions, $V_{s}$ should be capable of measurement within \pm 1 per cent. Under the conditions in Cairo, where the data of Table I were obtained, the error in measuring the volume injected was estimated to be no more than 5 per cent. The plasma and albumin solutions were made up in $500 \mathrm{ml}$. bottles, graduated at $50 \mathrm{ml}$. intervals. Consequently, when 1200 to $1500 \mathrm{ml}$. of plasma or albumin solution were injected, three such bottles were used. The plasma or albumin was infused through a standard infusion set with minimal loss of the infused solution. It is believed that the measurement of the solutions delivered from each bottle was accurate within $\pm 25 \mathrm{ml}$, or \pm 5 per cent. An error of 5 per cent in measurement of infused solution would cause an error of 5 per cent in the blood volume measurement.

Errors in specific gravity. With the infusion of $1500 \mathrm{ml}$. of plasma, errors of 0.0002 in $G_{s}$, $G_{B_{1}}$, and $G_{B_{2}}$, would cause an error of about 8 per cent in the blood volume calculated by Equation 2 , if the errors were all in such directions as to make their effects on the estimated blood volume additive, and the correct blood volume were 6 liters. If the injected plasma volume were decreased to $1000 \mathrm{ml}$. the error in estimated blood volume would be raised to \pm 11 per cent. If only $500 \mathrm{ml}$. of plasma were injected, the error would be \pm 20 per cent. If the subject's blood volume were less than 6 liters, the errors would all be less, because the changes in blood specific gravity caused by the plasma infusions would be greater, and vice versa. It should be noted, however, that the chance that the errors in all three specific gravity determinations may be in the direction to cause additive effects on the estimated blood volume is only 1 in 8 , so that in practice maximal error in blood volume estimation would not be frequently expected.

Probability of errors from other sources. The sum of the maximal errors due to measurement of volume of infused fluid and to measurements of specific gravity in the data of Table $I$, is estimated above at $5+9=14$ per cent. The error attributed by Gregersen $(12,13)$ to the dye method is \pm 5 per cent. . One would, therefore, expect, from errors in the gravity method, and the \pm 5 per cent error of the dye method, a maxi- 
mum deviation of $14+5=19$ per cent between blood volumes measured by specific gravity and by dye. The maximum deviation of blood volume estimates by Procedure A from volume estimated by the dye method, in the experiments of Table I, was 13 per cent. The fact that the maximal observed deviation was 13 per cent, is an indication that no serious sources of error, other than those of measuring $V_{s}$ and the specific gravities, affect the estimation of blood volume by the specific gravity procedure.

\section{SUMMARY}

A simple rapid method for estimating the blood volume based on the change in blood hemoglobin content or specific gravity effected by the infusion of a known volume of plasma is presented, together with a line chart which facilitates the calculation.

Data are given which validate the use of this method and the sources of error are discussed.

The authors wish to take this opportunity to thank Dr. M. A. B. Demardash Bey, Director of the Cairo Fever Hospital, for his interest in our studies and for the facilities which he placed at our disposal.

\section{BIBLIOGRAPHY}

1. Phillips, R. A., Van Slyke, D. D., Dole, V. P., Emerson, K. Jr., Hamilton, P. B., Archibald, R. M., Copper sulfate method for measuring specific gravities of whole blood and plasma. U. S. Navy Bumed News Letter, 1943, 1 (9), 1. To be published in extenso later.

2. Heller, V. G., and Paul, H., Changes in cell volume produced by varying concentrations of different anticoagulants. J. Lab. and Clin. Med., 1934, 19, 777.

3. Sherrington, C. S., and Copeman, S. M., Variations experimentally produced in the specific gravity of the blood. J. Physiol., 1893, 14, 52.
4. Rowntree, L. G., and Brown, G. E., The Volume of the Blood and Plasma in Health and Disease. W. B. Saunders Co., Philadelphia, 1929.

5. McIntosh, J. F., Møller, E., and Van Slyke, D. D., Studies of urea excretion. III. The influence of body size on urea output. J. Clin. Invest., 1928, $6,467$.

6. Valentin, G. G., Versuche über die in dem thierischen Korper enthaltene Blutmenge. Repert. f. Anat. u. Physiol., 1838, 3, 281.

7. Erlanger, J., Blood volume and its regulation. Physiol. Rev., 1921, 1, 177.

8. Gilder, H., Müller, O. H., and Phillips, R. A., Mixing time of T-1824 in the blood. Am. J. Physiol., 1940, 129, P362.

9. Hopper, J., Jr., Tabor, H., and Winkler, A. W., Simultaneous measurements of the blood volume in man and dog by means of Evans Blue Dye, T1824, and by means of carbon monoxide. I. Normal subjects. J. Clin. Invest., 1944, 23, 628.

10. Hopper, J., Jr., Winkler, A. W., and Elkinton, J. R., Simultaneous measurements of the blood volume in man and dog by means of Evans Blue Dye, T1824, and by means of carbon monoxide. II. Under abnormal conditions, including secondary shock. J. Clin. Invest., 1944, 23, 636.

11. Gregersen, M. I., and Rawson, R. A., The disappearance of T-1824 and structurally related dyes from the blood stream. Am. J. Physiol., 1943, 138, 698.

12. Gregersen, M. I., Boyden, A. A., and Allison, J. B., Comparison of plasma volume measured with the blue dye T-1824 and with beef albumin, beef globulin and the pneumococcus polysaccharide SIII. Federation. Proceedings, 1945, 4, 27.

13. Root, W. S., Roughton, F. J. W., and Gregersen, M. I., Simultaneous measurement of blood volume with dye (T-1824) and with carbon monoxide (improved method). Federation Proceedings, 1945, 4, 60.

14. Gregersen, M. I., and Gibson, J. G., 2nd, Conditions affecting the absorption spectra of vital dyes in plasma. Am. J. Physiol., 1937, 120, 494.

15. Gregersen, M. I., Personal communication.

16. Lowell, A., Cournand, A., and Richards, D. W., Personal communication. 